(C) Society for Benefit-Cost Analysis, 2016. This is an Open Access article, distributed under the terms of the Creative Commons Attribution-NonCommercial-NoDerivatives licence (http://creativecommons.org/licenses/by-nc-nd/4.0/), which permits non-commercial re-use, distribution, and reproduction in any medium, provided the original work is unaltered and is properly cited. The written permission of Cambridge University Press must be obtained for commercial re-use or in order to create a derivative work.

Semra Ozdemir*, F. Reed Johnson and Dale Whittington

\title{
Process, Ideology, and Willingness to Pay for Reducing Childhood Poverty
}

Abstract: We investigated the perceived value of government programs on earlychildhood development as a means of reducing childhood poverty. We incorporated preferences for the process as well as the outcome by developing two statedpreference survey instruments. One survey directly elicited respondents' willingness to pay specifically for high-quality, intensive, early-childhood development programs at federal and state levels. A second survey elicited respondents' preferences for increasing or decreasing taxes and reallocating expenditures between other government programs and early-childhood programs. We found that respondents cared greatly about how childhood poverty was reduced, not just reducing poverty per se. The perceived effectiveness of a program and ideological perspective were found to be important determinants of preferences for a poverty-reduction program. Respondents across all groups, including conservatives and respondents who perceived the effectiveness of early-childhood programs to be low, were not in favor of reducing the early-childhood program.

Keywords: childhood poverty; early-childhood program; ideology; other social policy; willingness to pay.

JEL classifications: H4; I3.

\section{Introduction}

High childhood poverty in the United States has been associated with high-school dropout rates among native-born children (Heckman \& LaFontaine, 2010) and

*Corresponding author: Semra Ozdemir, Duke-NUS Medical School, Singapore, e-mail: semra.ozdemir@duke-nus.edu.sg

F. Reed Johnson: Duke University, USA

Dale Whittington: University of North Carolina at Chapel Hill, USA and

Manchester Business School, UK 
low labor productivity (Heckman, 2008; Duncan, Magnuson, Kalil \& Ziol-Guest, 2012). The total economic value of increased production and higher quality of life that would accrue if childhood poverty were eliminated in the United States was estimated to be $\$ 500$ billion per year in 2008 dollars or $4 \%$ of total GDP (Holzer, Schanzenbach, Duncan \& Ludwig, 2008). This estimate included decreases in the annual aggregate US production of goods and services associated with childhood poverty, as well as reduced safety and well-being because of crime and poor health associated with adults who have grown up poor.

There is compelling evidence that investing in early-childhood education for disadvantaged children has long-term economic benefits to program participants and non-participants alike (Barnett \& Masse, 2007; Heckman, Moon, Pinto, Savelyev \& Yavitz, 2010). However, it is not clear whether the American public is willing to pay for such interventions. Eliciting preferences for a governmentfinanced early-childhood development program to reduce poverty poses several challenges. First, there could be skepticism about the likely success of large-scale early-childhood programs. Second, an intervention program funded or managed by the government is susceptible to polarized ideological views about the appropriate role and size of government. For example, early-childhood development can be considered to be a private domain which precludes outside intervention. Third, the ability of government to run interventions on producing successful outcomes could be questioned. Fourth, government programs are financed through taxes or public borrowing, and many taxpayers and their representatives object to increases in taxes for any purpose. Finally, the investment cost of early-childhood development has to be borne long before the benefits are realized.

Contrary to conventional economic models that specify utility in terms of final consumption alone, this study accounted for preferences over both the outcome (how much childhood poverty is reduced) and processes for obtaining povertyreduction benefits. We developed two stated-preference (SP) survey instruments to assess the value of early-childhood development programs. One survey directly elicited respondents' willingness to pay (WTP) specifically for high-quality, intensive, early-childhood development programs at federal and state levels. A second survey elicited respondents' preferences for increasing or decreasing taxes and reallocating expenditures between other government programs and early-childhood programs. Both surveys were web-enabled and administered in June 2012 by Knowledge Networks (KN) to about 4000 members of a nationally representative, US general population panel. 


\section{Background}

Previous studies have conducted economic analyses of experimental early-childhood development programs by attaching dollar values to realized program outcomes. Barnett and Masse (2007) measured benefit-cost ratios of 2.5 and 9 for the Abecedarian and Perry programs (two well-known experimental early-childhood interventions), respectively (Barnett \& Masse, 2007). Heckman et al. (2010) estimated an annual social rate of return of 7-10\% for the Perry program (Heckman et al., 2010). The net benefits to the non-participants constituted between $55 \%$ and $72 \%$ of the total net benefits, depending on the assumptions on the costs associated with crime and the deadweight cost of taxation. However, a direct comparison of the benefit-cost findings of different programs could be misleading, because the early-childhood development programs varied in terms of what outcomes they targeted and how the program outcomes were measured; and the economic evaluations also varied in terms of how these outcomes were valued in monetary terms (Karoly, 2012).

Previous studies also have shown that the cost savings from alleviating the causes of crime, unemployment, ill health, and other consequences of social inequities more than offset the costs of small-scale, high-quality early-childhood interventions (Barnett \& Masse, 2007; Heckman et al., 2010). However, the investment cost of early-childhood development has to be borne long before the social benefits are realized. People might prefer to give priority to more immediate needs, in addition to government efforts to find ways to cut spending while continuing to provide current services. Thus, the perceived shadow price of investing on earlychildhood development is greater than the simple cost estimates for early-childhood programs would suggest. It therefore is important to estimate taxpayers' preferences for allocating current public funds to early-childhood development programs. Policymakers and legislators want to know not only the returns on investments in early-childhood development, but also whether voters' perceived net benefits are sufficient to support such investments.

Perceived net benefits could be influenced by views on the likely effectiveness of poverty programs and views on the legitimacy of government interventions. Previous research has shown that political ideology, party affiliation, and political trust are highly correlated with attitudes toward government spending (Jacoby, 1994, 2006). Moreover, previous studies have shown that individuals and policy makers care about the mechanism by which funds are raised (Johnston, Swallow \& Weaver, 1999; Stevens, DeCoteau \& Willis, 1997) and political ideology is associated with preferences for wealth redistribution (Norton \& Ariely, 2011). Because government-provided early-childhood development programs involve social redis- 
tribution, we expect the factors that affect demand for redistribution to affect preferences for these programs as well. We expect that beliefs and perceptions on the causes of wealth and poverty redistribution (Alesina \& Angeletos, 2005; Fong, 2001), social mobility (Benabou \& Ok, 2001; Rainer \& Siedler, 2008), and expected future income (Alesina \& La Ferrara, 2005) play role on preferences for government programs to reduce childhood poverty.

\section{Conceptual framework}

Reducing childhood poverty provides benefits to taxpayers and children in poverty that may be realized in the short or long term (Belfield et al., 2015). Benefits to taxpayers include reduced crime rates, increased labor productivity, and reduced welfare use; while benefits to participants of the programs include better nutrition and better health care and benefits they receive later in life, such as higher earnings, better quality of life, and higher next-generation earnings. Altruistic individuals gain additional benefits from reducing childhood poverty if they care not only about their own share of social benefits but also about benefits to child beneficiaries and other taxpayers.

An individual's utility for childhood poverty rates is a function of benefits to taxpayers $G_{N}$ where $N$ represents taxpayers, and benefits to children $\left(B_{M}\right)$, where $M$ represents the number of children who receive help. We differentiate between social benefits to oneself $\left(G_{n}\right)$ and to other taxpayers $\left(G_{-n}\right)$, where $n$ represents an individual and $-n$ represents all other taxpayers. Altruism is represented analytically by making the beneficiary's consumption of the good an argument in the altruist's utility function if paternalistic and by making the beneficiary's utility an argument in the altruist's utility function if pure. ${ }^{1}$ Hence, individual $n$ 's utility function would be

$$
U_{n}=U\left(G_{n}, G_{-n}, U_{-n}\left(G_{-n}\right), B_{M}, U_{M}\left(B_{M}\right), Y_{n}, Z_{n}\right)
$$

where, assuming that preferences are beneficent,

$$
\begin{aligned}
& \partial U_{n} / \partial G_{n}>0, \quad \partial U_{n} / \partial G_{-n} \geqslant 0, \quad \partial U_{n} / \partial U_{-n} \geqslant 0, \\
& \partial U_{n} / \partial B_{M} \geqslant 0, \quad \partial U_{n} / \partial U_{M} \geqslant 0
\end{aligned}
$$

and $Y_{n}$ is individual $n$ 's disposable income and $Z_{n}$ is a vector of socio-economic characteristics. However, we allow for the possibility that preferences for reducing

1 The literature distinguishes between paternalistic and pure altruism. Pure altruism refers to the situation where an individual values the welfare of another individual, whereas paternalistic altruism refers to the situation where the altruist values the beneficiary's consumption of particular merit goods, irrespective of the beneficiary's preferences. 
childhood poverty are not independent of preferences for both how programs are financed and the mechanism used. Thus, the perceived benefits of reducing childhood poverty will be a function of a number of additional factors as follows:

$\alpha_{n}=f\left(S, I, D_{n}\right)$ : Perceived effectiveness, denoted by $\alpha_{n}$, is defined as whether an individual considers an intervention program as effective in reducing childhood poverty. It affects $G_{N}$ and $B_{M}$. Perceived effectiveness is a function of the scale of the program (S), the type of institution funding the program, such as federal $\left(I^{F E D}\right)$ or state $\left(I^{\text {STATE }}\right)$ governments, and ideology $\left(D_{n}\right)$. The scale of the program (S) affects perceived effectiveness based on whether individuals believe that small-scale programs can be implemented successfully for large numbers of children or not. Some people may believe that state programs are more competently run than federal programs.

$L_{n}=f\left(I, D_{n}\right)$ : Perceived legitimacy $\left(L_{n}\right)$ is defined as the extent to which individuals consider early-childhood programs to be a legitimate form of government and non-government intervention. Perceived legitimacy thus affects perceived benefits to both direct and indirect beneficiaries and is assumed to be a function of the type of institution funding the program $(I)$ and ideology $\left(D_{n}\right)$.

Based on these factors, individual $n$ 's utility function for an early-childhood program would be

$U_{n}=U\left(G_{n}\left(\alpha_{n}, L_{n}, t\right), G_{-n}\left(\alpha_{n}, L_{n}\right), U_{-n}\left(G_{-n}\right), B_{M}\left(\alpha_{n}, L_{n}\right), U_{M}\left(B_{M}\right), Y_{n}, Z_{n}\right)$.

Note that there is latency $(t)$ between investing in young children and realized social benefits to the tax payers and benefits to the children. However, although $G_{n}$ is a function of $t$, altruistic benefits, such as $G_{-n}$ are not a function of $t$ when they enter individual $n$ 's utility function. This is because individual $n$ receives altruistic benefits right away when helping children even though the consumption of these benefits by others would be in the future.

The perceived effectiveness and perceived legitimate role of government are expected to be positively associated with utility $((\partial U / \partial G)(\partial G / \partial \propto) \geqslant 0$, $(\partial U / \partial B)(\partial B / \partial \propto) \geqslant 0$, and $(\partial U / \partial G)(\partial G / \partial L) \geqslant 0,(\partial U / \partial B)(\partial B / \partial L) \geqslant 0)$, while time is expected to be negatively associated with utility $((\partial U / \partial G)(\partial G / \partial t)$ $\leqslant 0)$.

\section{Methods}

We used both contingent valuation (CV) and discrete-choice experiment (DCE) surveys to obtain money-equivalent values for program benefits because there are no market prices for such public goods. The value of a high-quality government 
program for early-childhood development was derived from the utility function in equation (2). The data collected with both SP methods are interpreted using random-utility theory. Letting $\boldsymbol{X}^{\text {CHILD }}$ denote a vector of perceived benefits to individual $n$ from an early-childhood program, individual $n$ 's utility will be

$$
U_{n}=V\left(\boldsymbol{X}^{C H I L D}, Y_{n}, \boldsymbol{Z}_{n}\right)+\varepsilon_{n}
$$

where $V$ and $\varepsilon$ denote systematic and random components of utility, respectively, and

$$
\boldsymbol{X}^{C H I L D}=G_{n}\left(\alpha_{n}, L_{n}, t\right), G_{-n}\left(\alpha_{n}, L_{n}\right), U_{-n}\left(G_{-n}\right), B_{M}\left(\alpha_{n}, L_{n}\right), U_{M}\left(B_{M}\right)
$$

from equation (2). WTP for the program will be the solution to

$$
V\left(\boldsymbol{X}_{0}^{C H I L D}, Y_{n}, \boldsymbol{Z}_{n}\right)+\varepsilon_{0}=V\left(\boldsymbol{X}_{1}^{C H I L D}, Y_{n}-W T P, \boldsymbol{Z}_{n}\right)+\varepsilon_{1}
$$

where $\boldsymbol{X}_{0}^{\text {CHILD }}$ denotes perceived benefits at the status quo and $\boldsymbol{X}_{1}^{C H I L D}$ denotes improved perceived benefits.

The CV survey focused solely on respondents' willingness to pay higher taxes for a high-quality early-childhood program. The questionnaire first introduced Heckman's findings (Heckman et al., 2010) on investing in early childhood and highlighted the main results from the Perry and Abecedarian early-childhood programs. The web-enabled survey also presented a 1-minute video of Heckman describing his findings. ${ }^{2}$ To test the effect of institution (federal versus state-level programs) and the scale of the program (small versus large-scale program) on WTP for an early-childhood program, respondents randomly were assigned to evaluate one of four hypothetical programs: (1) a federal, small-scale program; (2) a federal, large-scale program; (3) a state-level, small-scale program; and (4) a state-level, large-scale program. The small-scale program targeted only the beneficiaries of current programs (about 1.1 million children at the time of the survey) and largescale program targeted about $90 \%$ of children under the age of 6 in poverty. The payment method was identified as federal or state taxes, depending on program type. CV question can be found in the appendix.

The effect of the scale of program and type of institution on WTP values in the CV survey depends on whether program size or perceived effectiveness dominates. Assuming monotonic preferences, we expect $W T P_{L A R G E}>W T P_{S M A L L}$ and $W T P_{\text {FEDERAL }}>W T P_{\text {STATE }}$, because a large-scale program or a federal-level program would target a larger number of children than a small-scale program or a statelevel program, respectively. However, if individuals believe that program effective-

2 A short version of Heckman's "The Urgency of Now" video was used. The original video, which is provided for public use, can be found at http://www.heckmanequation.org/. 
Table 1 DCE survey: Attribute levels for the early-childhood development program and taxes.

\begin{tabular}{ll}
\hline Attribute & Level \\
\hline Intensive early-childhood & - $50 \%$ worse: 210,000 children can participate \\
development program & - $25 \%$ worse: 320,000 children can participate \\
& - No change: 430,000 children can participate \\
& - $25 \%$ improvement: 530,000 children can participate \\
& - $50 \%$ improvement: 640,000 children can participate \\
Effects on household taxes & - You pay $\$ 2000$ more per year $(\$ 170$ more per month) in taxes than now \\
& - You pay $\$ 300$ more per year $(\$ 25$ more per month) in taxes than now \\
& - You pay $\$ 50$ more per year $(\$ 4$ more per month) in taxes than now \\
& - No change: Same amount of taxes as now \\
& - You pay $\$ 50$ less per year $(\$ 4$ less per month) in taxes than now \\
& - You pay $\$ 300$ less per year $(\$ 25$ less per month) in taxes than now \\
& - You pay $\$ 2000$ less per year $(\$ 170$ less per month) in taxes than now \\
\hline
\end{tabular}

ness decreases as the program size increases, then $W T P_{S M A L L}>W_{T P} P_{L A R G E}$ and $W T P_{\text {STATE }}>W T P_{\text {FEDERAL }}$.

In contrast to the conventional direct value elicitation used in the CV survey, the DCE survey asked respondents to consider a realistic budget-allocation problem in which a group of programs was competing for the same resources. The questionnaire presented respondents with hypothetical budget alternatives in which an early-childhood program competed with three other government programs funded by specified individual federal income-tax burdens. The survey offered increases and decreases in taxes and in early-childhood programs, allowing respondents to express preferences for smaller and larger government budgets as well as for reallocations within existing budgets. Program benefits were defined in terms of the number of beneficiaries; this number was presented both in relative (e.g., $50 \%$ improvement) and absolute (e.g., 640,000 children can participate) terms. ${ }^{3}$ Because a substantial portion of American citizens do not pay federal income taxes, ${ }^{4}$ an incometax credit was used for those who receive earned-income-tax credits. ${ }^{5}$ Table 1

3 Although about 1.1 million children under the age of 6 participated in the standard early-childhood programs at the time of the survey, only 430,000 children could participate in the new intensive earlychildhood programs (as described in the survey) using the existing government funds used for these programs.

4 The information was accessed at http://www.taxpolicycenter.org/UploadedPDF/1001547-Why-No-I ncome-Tax.pdf on March 2012.

5 The analysis of the DCE survey in this paper was based on the "tax" version because the sample size for the "tax-credit" version was very small. 
If these were the only two alternatives, which one would you want your Congressman to vote for?

\begin{tabular}{|c|c|c|}
\hline & Alternative A & Alternative B \\
\hline Disaster-relief program & $\begin{array}{c}\text { 50\% improvement: } \\
\text { 270,000 households can } \\
\text { be assisted }\end{array}$ & $\begin{array}{c}\text { No change: } \quad 180,000 \\
\text { households can be } \\
\text { assisted }\end{array}$ \\
\hline $\begin{array}{l}\text { Intensive early-childhood } \\
\text { development program }\end{array}$ & $\begin{array}{l}\text { 50\% worse: } \quad 210,000 \\
\text { children can participate }\end{array}$ & $\begin{array}{l}\mathbf{2 5 \%} \text { worse: } \\
320,000 \text { children can } \\
\text { participate }\end{array}$ \\
\hline $\begin{array}{l}\text { Food-safety monitoring } \\
\text { program }\end{array}$ & $\begin{array}{c}\mathbf{2 5} \% \text { worse: } \\
165,000 \text { severe food } \\
\text { poisoning cases }\end{array}$ & $\begin{array}{l}\text { 25\% improvement: } \\
\text { 100,000 severe food } \\
\text { poisoning cases }\end{array}$ \\
\hline Effects on household taxes & $\begin{array}{c}\text { You pay } \$ 2,000 \text { less per } \\
\text { year }(\$ 170 \text { less per } \\
\text { month) in taxes than } \\
\text { now }\end{array}$ & $\begin{array}{l}\text { You pay } \$ 50 \text { more per } \\
\text { year (\$4 more per month) } \\
\text { in taxes than now }\end{array}$ \\
\hline $\begin{array}{l}\text { Which alternative would you } \\
\text { like your Congressman to vote } \\
\text { for? }\end{array}$ & & \\
\hline
\end{tabular}

Figure 1 A sample DCE trade-off question.

presents the programs and expenditure levels used in this survey, and Figure 1 presents a sample trade-off question.

Individual $n$ 's utility for budget preferences would be

$$
U_{n}=V\left(\boldsymbol{X}^{\text {CHILD }}, \boldsymbol{X}^{\text {OTHER }}, Y_{n}\right)+\varepsilon_{n},
$$

where $\boldsymbol{X}^{O T H E R}$ is a vector of perceived benefits associated with the other government programs. ${ }^{6}$ Similar to the early-childhood program, an individual benefits from his/her share of the social benefits, and altruistic benefits for benefits to the other taxpayers and program participants. Individual $n$ chooses alternative $i$ over alternative $j(i \neq j)$ if and only if

$$
\begin{aligned}
& V\left(\boldsymbol{X}_{i}^{\text {CHILD }}, \boldsymbol{X}_{i}^{\text {OTHER }}, Y_{n}-C_{i}, Z_{n}\right) \\
& \quad-V\left(\boldsymbol{X}_{j}^{C H I L D}, \boldsymbol{X}_{j}^{\text {OTHER }}, Y_{n}-C_{j}, Z_{n}\right)>\left(\varepsilon_{n j}-\varepsilon_{n i}\right)
\end{aligned}
$$

6 We focus only on the poverty-reduction results in this paper. Results for other programs have been reported in Ozdemir, Johnson and Whittington (2016). 
where $C_{i}$ and $C_{j}$ are the costs and $\varepsilon_{n i}$ and $\varepsilon_{n j}$ are the error terms associated with alternative $i$ and $j$, respectively.

With regard to the two SP methods, the CV method has extensively been used in benefit-cost analysis of public investments and regulatory impacts (Bishop \& Welsh, 1992; Diener, O'Brien \& Gafni, 1998; Mitchell \& Carson, 2013). However, there are three well-known disadvantages of the CV method. First, WTP values from CV applications may be overestimated because the method focuses on only one policy scenario at a time. Ignoring competing budget priorities and possible substitutes and opportunity costs by focusing on a single policy can cause respondents to exaggerate the importance of that policy (Kahneman \& Sugden, 2005). While focus bias may have been reduced in this study by giving respondents time to think after introduction to the CV scenario but before they answered the CV question, possible consideration of substitutes and opportunity costs was unobserved and thus was not experimentally controlled.

Second, findings on the sensitivity of CV studies to scope have been mixed (Heberlein, Wilson, Bishop \& Schaeffer, 2005). This study could fail a scope test for several reasons. The early-childhood program may not be considered a desired good by everyone and these individuals might have supported a smaller scale program that would target only the most impoverished children, rather than a larger scale program. Also, subjects who were skeptical of government's ability to successfully implement a large national program might be willing to support a smaller program, but would be much less likely to support a larger program. The likely effect of insensitivity to scope would be large standard errors. To control for factors other than scope, we investigated the influence of type of institution and perceived program effectiveness on WTP.

Third, WTP values in CV applications could be overestimated because of social desirability bias - over-reporting socially approved behaviors or attitudes, and under-reporting socially disapproved behaviors (Lindhjem \& Navrud, 2011). Social desirability bias, however, might not be a major problem in this study because internet surveys were used. Research has indicated that the threat of social desirability bias is reduced in internet compared to phone interviews (Chang \& Krosnick, 2010; Holbrook \& Krosnick, 2010; Kreuter, Presser \& Tourangeau, 2008) and face-toface interviews (Heerwegh, 2009). Moreover, social acceptability bias could have worked in opposite directions for liberal and conservative respondents.

DCEs quantify the implicit utility parameters of features and feature levels elicited through a series of trade-off tasks that require respondents to choose among alternative scenarios with different combinations of features. The advantages of the DCE method in this application are that it allowed respondents to consider both outcome and process attributes of the programs, as well as both increases and decreases 
in taxes. DCE thus simulates a realistic decision frame requiring tradeoffs among multiple government programs competing for larger or smaller government budgets. Although both CV and DCE methods have been used for budget reallocation scenarios (Bergstrom, Boyle \& Yabe, 2004; Swallow \& McGonagle, 2006; Koford, 2010), DCE had an important advantage for this application: it allowed us to estimate the effect of process and ideological factors on perceived values. However, DCE surveys are cognitively more challenging than the CV question because they require each respondent to answer multiple, relatively more complicated choice questions. Possible measurement error could lead to decreased precision and parameter estimates that are biased toward zero. However, giving respondents time to think could mitigate these effects as respondents had more time to evaluate program alternatives before answering the DCE choice tasks.

Both types of SP studies are likely to receive protest responses for new taxes or for any increase in existing taxes in the current political climate. The budgetallocation framework in the DCE survey could mitigate the effect of tax aversion by (1) offering decreases in taxes, and (2) reminding respondents about the opportunity costs of public dollars by presenting other programs that were competing for same resources. We investigated protest responses in the CV survey by identifying respondents who indicated that they did not vote for the program because they were against any tax increase.

It is not, however, possible to directly compare the mean WTP values from the two survey instruments because they targeted different numbers of children, and their contexts and framing differed. Moreover, WTP values from the DCE survey should be interpreted as the net WTP values accounting for the perceived welfare loss from using fewer public dollars on other government programs. While this is not the case for WTP values from the CV survey, such net values are more relevant for policy evaluations.

Respondents completed either the CV survey or the DCE survey. CV respondents were randomly assigned to one of seven annual tax increases: $\$ 10, \$ 25, \$ 50$, $\$ 100, \$ 300, \$ 1000$, and $\$ 2000$. The tax-attribute levels in the DCE survey were $\$ 2000$ more/less, \$300 more/less, \$50 more/less, and no change. A common algorithm was implemented in SAS (Sas \& Guide, 1990) to construct a near-optimal Defficient experimental design for the DCE survey (Johnson, Kanninen, Bingham \& Özdemir, 2007). To reduce respondent burden, the trade-off questions were divided into 14 blocks of 10 questions within the DCE survey, and each respondent was randomly assigned to one of the blocks. To minimize possible order effects, the sequence of the trade-off questions was randomized.

Both web-enabled survey instruments were hosted on a secure site and were administered in June 2012 to respondents in KN's nationally representative gen- 
eral population panel. A similar survey structure and design was followed in both questionnaires. A time-to-think approach (Whittington et al., 1992) was used where respondents were presented with SP scenarios and questions in the first half of the survey, but answered the SP questions one to 10 days later after having time to think about the questions.

A binomial-probit interval-regression model was used to analyze the binary response data from the $\mathrm{CV}$ question. The dependent variable was a dummy variable equal to 1 if respondents voted for paying higher taxes to fund the earlychildhood program and was certain or very certain of their answers, and 0 otherwise. ${ }^{7}$ Mixed-logit (also known as random-parameters logit) models (McFadden \& Train, 2000) were employed to analyze the DCE trade-off questions. Mixed-logit models have advantages over conditional-logit models because mixed-logit is not subject to the assumption of independence of irrelevant alternatives, accommodates correlations among panel observations, and accounts for unobserved heterogeneity in tastes across respondents.

Two linear variables were created for each attribute: one for increases and the other for decreases to allow for different slopes for in the gain and loss domains. The basic empirical model for the budget data was defined as:

$$
V=\beta_{i n c}^{k} X_{i n c}^{k}+\beta_{d e c}^{k} X_{d e c}^{k}+\mu_{i n c} \text { Cost }_{i n c}+\mu_{d e c} \operatorname{Cost}_{d e c}
$$

where $X^{k}$ indicates the outcome of government program $k$. Marginal WTP was calculated by dividing a change in the utility of a program attribute by the marginal utility of income, generally interpreted as the absolute value of the cost parameter. We used the estimate of the cost-increase parameter in equation (6) as the marginal utility of income to calculate willingness to pay. ${ }^{8}$ For example, WTP for an increase in the early-childhood program was calculated as:

$$
W T P=\frac{\beta_{i n c}^{\text {child }} \cdot \Delta X_{i n c}^{\text {child }}}{-\mu_{i n c}}
$$

NLOGIT 4.0 (Greene, 2007) was used for all the econometric analyses. One thousand Halton draws were used for the mixed-logit estimates. All attribute parameters except the cost parameters were specified as normally distributed; and cost parameters were assumed to be nonrandom (Revelt \& Train, 2000). ${ }^{9}$

7 When the dependent variable was identified as 1 if respondents voted for the program was very certain of their answers, the number of yes responses decreased from $41 \%$ to $16 \%$, and WTP estimates were found to be non-positive.

8 Using the cost-decrease parameter as the marginal utility of income provides the willingness to accept. In this paper, we are not interested in willingness to accept values because there are no property rights involved. Specification tests indicated that the marginal utility of income was constant.

9 Assuming triangular distribution for all parameters produced very similar results. When parameters were assumed to be log-normally distributed, the models did not converge. 


\section{Results}

\subsection{Survey samples}

The CV and DCE surveys were administered to 1712 and 2037 respondents, respectively. Table 2 presents the descriptive statistics for both surveys. The distribution of the demographic characteristics and the mean values were very similar between the surveys. Based on the U.S. Census Bureau statistics, ${ }^{10}$ the main differences between the internet-panel samples and the general population are in somewhat lower representation of females ( $47 \%$ versus 51\%), African Americans (9\% versus $13 \%$ ) and Hispanics (8\% versus $17 \%$ ), and slightly higher representation of college graduates ( $34 \%$ versus $30 \%)$. The median income of the sample ( $\$ 55 \mathrm{k})$ was about the same as the median household income $(\$ 53 \mathrm{k})$ in the United States.

Poverty was reported to be one of the two most important priorities in the United States by about $13 \%$ of the respondents, while about $15 \%$ reported that it was one of the two least important priorities. About $14 \%$ and $16 \%$ of the respondents indicated that one of their children or a family member's children had participated in a current government program on early-childhood development (e.g., Head Start) in the CV and DCE surveys, respectively. A factor analysis combined gun control, abortion, and self-identified political ideology questions into an "ideology" factor. The ideology factor score was used to assign each respondent to a specific ideological group for analysis. Respondents in the highest $30 \%$ of the ideology factor-score distribution were classified as liberals and respondents in the lowest $30 \%$ of the distribution were classified as conservatives. The rest were considered to be moderates.

Perceived effectiveness was measured by a question on how effective respondents thought the early-childhood intervention programs (as described in the questionnaire) would be in reducing poverty. In the CV survey, respondents were asked about the likely success of a program when funded by the (1) federal government, (2) state governments, and (3) local governments or private institutions (Figure 2).

Conservatives had the most confidence in local government or private institutions, and the least confidence in federal government. Moderates and liberals supported all three types of institutions about equally, although a larger percentage of liberals had more confidence in these institutions than other groups. Overall, $27 \%$ of respondents reported early-childhood intervention programs to be unlikely or very unlikely to be effective if funded by the federal government. The corresponding figures were $21 \%$ and $12 \%$ if funded by state governments, and local

10 The U.S. Census Bureau statistics was accessed at http://www.census.gov/ on March 13, 2013. 
Table 2 Demographic characteristics.

\begin{tabular}{|c|c|c|}
\hline & CV survey $N=1712$ & DCE survey $N=2037$ \\
\hline \multicolumn{3}{|l|}{ Gender, $\%$} \\
\hline Male & 54 & 52 \\
\hline Female & 46 & 48 \\
\hline Age, mean (SD), years & $53(16)$ & $52(16)$ \\
\hline \multicolumn{3}{|l|}{ Marital status, $\%$} \\
\hline Married & 60 & 60 \\
\hline Widowed & 5 & 5 \\
\hline Divorced/separated & 12 & 13 \\
\hline Single & 16 & 16 \\
\hline Living with partner & 7 & 6 \\
\hline \multicolumn{3}{|l|}{ Race/ethnicity, $\%$} \\
\hline White & 78 & 76 \\
\hline Hispanic & 7 & 8 \\
\hline African American & 9 & 9 \\
\hline 2 or more races & 3 & 3 \\
\hline Other & 3 & 3 \\
\hline \multicolumn{3}{|l|}{ Highest education, $\%$} \\
\hline Less than high school graduate & 8 & 8 \\
\hline High school or equivalent (e.g., GED) & 27 & 27 \\
\hline Some college & 31 & 30 \\
\hline Bachelor's or graduate degree (e.g., BA, BS) & 34 & 35 \\
\hline \multicolumn{3}{|l|}{ Employment, \% } \\
\hline Paid employee & 46 & 48 \\
\hline Self-employed & 7 & 8 \\
\hline Temporary layoff from a job & 1 & 1 \\
\hline Looking for work & 8 & 6 \\
\hline Retired & 25 & 23 \\
\hline Disabled & 7 & 7 \\
\hline Other & 6 & 7 \\
\hline Household Income, mean (SD), \$ & $69 \mathrm{~K}(49 \mathrm{~K})$ & $72 \mathrm{~K}(49 \mathrm{~K})$ \\
\hline Household size, mean (SD) & $2.6(1.4)$ & $2.6(1.5)$ \\
\hline 1 child between 0 and 5 & 11 & 11 \\
\hline 2 or more children between 0 and 5 & 2 & 2 \\
\hline
\end{tabular}




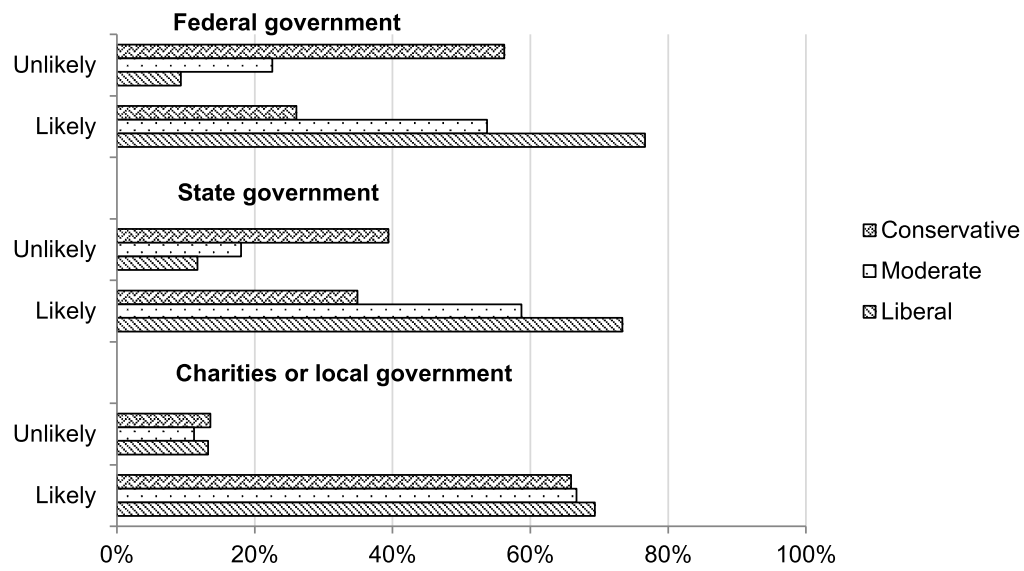

Figure 2 Opinions on likely success of early-childhood programs funded by federal, state and local governments, and private charities, by ideology.

governments/private institutions, respectively. In the DCE survey, $30 \%$ of respondents indicated a low likelihood of success for the early-childhood program to reduce poverty. The low chances of success were indicated by $54 \%$ of conservatives, $25 \%$ of moderates, and $14 \%$ of liberals in the DCE survey sample.

\subsection{Parameter estimates}

Perceived effectiveness, other attitudinal questions, ideology, and socio-economic characteristics were used to explain individuals' willingness to pay for the earlychildhood program. Table 3 presents three sets of binomial-probit estimates for the single-bounded CV question. The first model estimated the effect of household income and program features, such as tax level, state-level administration, and scale of the program. The second model added other socio-economic characteristics and dummy variables indicating perceived program ineffectiveness to the first model. The third model included the variables in the second model plus variables indicating respondents' ideology and attitudes toward government spending and public programs.

Tax level and annual household income parameter estimates were significant with correct signs at the $1 \%$ level (Table 3). ${ }^{11}$ The dummy variable for state-level

11 From this point forward, significance is considered to be at the $1 \%$ level if not otherwise specified. 
Table 3 CV survey binomial-probit estimates.

\begin{tabular}{|c|c|c|c|}
\hline & $\begin{array}{r}\text { Model } 1 \\
\text { coefficient } \\
\text { (St. Err.) }\end{array}$ & $\begin{array}{r}\text { Model } 2 \\
\text { coefficient } \\
\text { (St. Err.) }\end{array}$ & $\begin{array}{r}\text { Model 3 } \\
\text { coefficient } \\
\text { (St. Err.) }\end{array}$ \\
\hline Tax level & $\begin{array}{r}-7.10 \mathrm{E}-04 * * * \\
(5.54 \mathrm{E}-05)\end{array}$ & $\begin{array}{r}-7.50 \mathrm{E}-04 * * * \\
(5.75 \mathrm{E}-05)\end{array}$ & $\begin{array}{r}-8.80 \mathrm{E}-04 * * * \\
(6.81 \mathrm{E}-05)\end{array}$ \\
\hline State-level program & $\begin{array}{r}0.006 \\
(0.064)\end{array}$ & $\begin{array}{r}0.001 \\
(0.066)\end{array}$ & $\begin{array}{r}0.071 \\
(0.132)\end{array}$ \\
\hline Small-scale program & $\begin{array}{l}-0.010 \\
(0.064)\end{array}$ & $\begin{array}{l}-0.015 \\
(0.066)\end{array}$ & $\begin{array}{r}0.019 \\
(0.076)\end{array}$ \\
\hline Household income & $\begin{array}{r}3.57 \mathrm{E}-06^{* * * *} \\
(6.67 \mathrm{E}-07)\end{array}$ & $\begin{array}{r}3.70 \mathrm{E}-06 * * * \\
(7.59 \mathrm{E}-07)\end{array}$ & $\begin{array}{r}4.05 \mathrm{E}-06^{* * * *} \\
(8.96 \mathrm{E}-07)\end{array}$ \\
\hline BS degree & & $\begin{array}{r}0.169 * * \\
(0.075)\end{array}$ & $\begin{array}{r}0.126 \\
(0.088)\end{array}$ \\
\hline White & & $\begin{array}{l}-0.104 \\
(0.080)\end{array}$ & $\begin{array}{r}0.047 \\
(0.097)\end{array}$ \\
\hline Male & & $\begin{array}{l}-0.038 \\
(0.066)\end{array}$ & $\begin{array}{r}0.059 \\
(0.077)\end{array}$ \\
\hline Age & & $\begin{array}{r}0.002 \\
(0.002)\end{array}$ & $\begin{array}{l}0.0002 \\
(0.003)\end{array}$ \\
\hline Program ineffective under federal government & & $\begin{array}{r}-0.529 * * * \\
(0.102)\end{array}$ & $\begin{array}{r}-0.261^{* *} \\
(0.117)\end{array}$ \\
\hline Program ineffective under state governments & & $\begin{array}{r}-0.365^{* * *} \\
(0.111)\end{array}$ & $\begin{array}{r}-0.415^{* * * *} \\
(0.122)\end{array}$ \\
\hline Living in a high-poverty area & & & $\begin{array}{r}0.353^{* *} \\
(0.173)\end{array}$ \\
\hline Has a child in Head Start & & & $\begin{array}{r}0.106 \\
(0.113)\end{array}$ \\
\hline $\begin{array}{l}\text { Responsible for helping the poor: } \\
\text { Federal government }{ }^{\dagger}\end{array}$ & & & $\begin{array}{r}0.683 * * * \\
(0.152)\end{array}$ \\
\hline $\begin{array}{l}\text { Responsible for helping the poor: } \\
\text { State governments }{ }^{\dagger}\end{array}$ & & & $\begin{array}{r}0.006 \\
(0.182)\end{array}$ \\
\hline
\end{tabular}


Table 3 (Continued).

Responsible for helping the poor:

Poor themselves ${ }^{\dagger}$

Liberal

Conservative

"Federal government"-State-level program

“State government"_State-level program

"Poor themselves"_State-level program

Constant

$N$ of observations

Log likelihood

1698

1698

AIC

$-1046$

$-986$

$-743$

*I

1.24

1.17 the $1 \%$ level.

$\dagger$ These are the categories for the question about which group should be the most responsible for helping the poor.

$¥$ Interaction variables between the categories for the question about which group should be the most responsible for helping the poor and a dummy variable indicating a state-level program.

programs was not significant; however, people who believed that "federal government" should be responsible for the poor were less likely to support the state-level program than the federal-level program. The dummy variable for the small-scale program was not significant. These findings suggest that neither institution (federal versus state government) nor the scale of the program was significant determinants of WTP.

Reporting low likelihood of success on the effectiveness of the programs and being conservative were negatively associated with supporting the programs, as expected. Believing that the federal government should be responsible for the poor and being liberal were positively associated with supporting the early-childhood program. Having a college degree and living in a perceived high-poverty area also was a significant determinant of WTP at the $5 \%$ level. 
A follow-up question on why respondents supported or opposed the program indicated early-childhood development to be seen as an illegitimate role for the government by conservatives. First, early-childhood development was seen as a private matter and governmental involvement was considered intrusive. Twenty percent of conservatives indicated government intrusion as the primary reason for voting against the early-childhood program in the CV survey. In addition, $26 \%$ of conservatives indicated that extended family should be responsible for early-childhood care. Second, conservatives did not think it was government's responsibility to fund these programs. About $10 \%$ of conservatives indicated inappropriate assignment of responsibility as the primary reason for voting against the program and $21 \%$ of conservatives indicated this item when asked about current government programs related to early childhood. Third, being against any new tax increases contributed to being against government programs related to early childhood. Aversion to tax increases was selected as the primary reason for voting against the program by $18 \%$ of conservatives.

Table 4 presents the mixed-logit parameter estimates for the poverty-reduction program and taxes in the DCE survey for three different models: (1) a maineffects model (Model 1), (2) interactions with perceived effectiveness; for example, the early-childhood parameters were interacted with a dummy variable indicating low likelihood of success for the early-childhood program to reduce poverty (Model 2), and (3) interactions with ideology ${ }^{12}$ (Model 3). The parameter estimate for decreases in the early-childhood program was significantly negative for all groups in all three models. The parameter estimate for increases in the earlychildhood program was significant in the main-effects model. In Model 2, it was not significant for respondents who perceived the early-childhood programs as ineffective; but it was significantly positive for others. In Model 3, the parameter estimate for increases in the early-childhood program was significantly positive for liberals and moderates, and was not significant for conservatives. The findings on the perceived effectiveness and ideological groups were consistent with the findings in the CV survey.

The slope of the utility function for program decreases was much steeper than the slope of the utility function for program increases in all models, indicating preference asymmetry for gains and losses. Thus, the utility loss from program decreases was larger than the utility gain from the corresponding program increases. The parameter estimate for tax increases was significantly negative for all groups in all three models. The parameter estimates for tax decreases in Models 1 and 2 were significantly positive for all respondents. It was also significantly positive for

12 We also tried interactions with perceived effectiveness and ideology in the same model, but the model did not converge. 
Table 4 DCE survey mixed-logit parameter estimates.

\begin{tabular}{|c|c|c|c|c|c|c|c|c|c|}
\hline & \multicolumn{2}{|c|}{ Model 1} & \multicolumn{3}{|c|}{ Model $2^{\dagger}$} & \multicolumn{4}{|c|}{ Model 3} \\
\hline & $\begin{array}{l}\text { Main- } \\
\text { effects }\end{array}$ & $\begin{array}{l}\text { Main- } \\
\text { effects }\end{array}$ & $\begin{array}{l}\text { Neutral or } \\
\text { effective }\end{array}$ & Ineffective & $\begin{array}{l}\text { Main- } \\
\text { effects }\end{array}$ & Moderates & Liberal & Conservative & $\begin{array}{l}\text { Main- } \\
\text { effects }\end{array}$ \\
\hline & $\begin{array}{l}\text { Parameter } \\
\text { (St. Error) }\end{array}$ & $\begin{array}{r}\text { St. Dev } \\
\text { (St. Error) }\end{array}$ & $\begin{array}{l}\text { Parameter } \\
\text { (St. Error) }\end{array}$ & $\begin{array}{l}\text { Parameter } \\
\text { (St. Error) }\end{array}$ & $\begin{array}{r}\text { St. Dev } \\
\text { (St. Error) }\end{array}$ & $\begin{array}{l}\text { Parameter } \\
\text { (St. Error) }\end{array}$ & $\begin{array}{l}\text { Parameter } \\
\text { (St. Error) }\end{array}$ & $\begin{array}{l}\text { Parameter } \\
\text { (St. Error) }\end{array}$ & $\begin{array}{r}\text { St. Dev } \\
\text { (St. Error) }\end{array}$ \\
\hline \multirow{2}{*}{$\begin{array}{l}\text { Decrease in early- } \\
\text { child program }\end{array}$} & $-0.032 * * *$ & $0.043 * * *$ & $-0.042 * * *$ & $-0.008 * *$ & $0.038 * * *$ & $-0.033 * * *$ & $-0.049 * * *$ & $-0.017 * * *$ & $0.041 * * *$ \\
\hline & $(0.002)$ & $(0.003)$ & $(0.002)$ & $(0.003)$ & $(0.003)$ & $(0.003)$ & $(0.004)$ & $(0.003)$ & $(0.003)$ \\
\hline \multirow{2}{*}{$\begin{array}{l}\text { Increase in early- } \\
\text { child program }\end{array}$} & $0.011 * * *$ & $0.027 * * *$ & $0.015 * * *$ & 0.001 & $0.027 * * *$ & $0.011 * * *$ & $-0.021 * * *$ & 0.002 & $0.026 * * *$ \\
\hline & $(0.002)$ & $(0.003)$ & $(0.002)$ & $(0.003)$ & $(0.003)$ & $(0.003)$ & $(0.003)$ & $(0.003)$ & $(0.003)$ \\
\hline \multirow{2}{*}{ Increase in taxes } & $-10.918^{* * *} *$ & & $-10.696 * * *$ & $-10.463 * * *$ & & $-10.756^{* * * *}$ & $-10.633 * * *$ & $-10.508^{* * * *}$ & \\
\hline & $(0.461)$ & & $(0.453)$ & $(0.464)$ & & $(0.465)$ & $(0.465)$ & $(0.462)$ & \\
\hline \multirow{2}{*}{ Decrease in taxes } & $0.338 * * *$ & & $0.147 * * *$ & $0.802 * * *$ & & $0.120^{*}$ & -0.075 & $0.523 * * *$ & \\
\hline & $(0.042)$ & & $(0.044)$ & $(0.077)$ & & $(0.067)$ & $(0.081)$ & $(0.070)$ & \\
\hline
\end{tabular}

* Indicates statistical significance at the $10 \%$ level, ** indicates at the $5 \%$ level, and *** indicates at the $1 \%$ level.

$\dagger$ This model provides estimates for respondents who indicated a neutral or high likelihood of success (titled "Neutral or Effective") and low likelihood of success (titled "Ineffective") for a government program on early-childhood development in helping children to break out of poverty. 
conservatives and moderates, but was not significant for liberals in Model 3. As in the case of government programs, the slope of the utility function for tax increases was much steeper than the slope of the utility function for tax decreases.

Standard deviations of random parameters provide information on unobserved taste heterogeneity. The significant standard deviations associated with the program parameters indicated significant unobserved taste heterogeneity in these attributes and confirmed the importance of estimating a mixed-logit model. The standard deviation was larger for decreases in the early-childhood program than increases in the program, which indicates more heterogeneous preferences for decreases in this program than for increases.

\subsection{WTP estimates}

Table 5 presents the mean annual WTP (standard errors in parentheses) per household for each survey in 2015 US dollars. In the CV survey based on Model 3 presented in Table 3, indicating that a federal program would be effective or neutral was associated with an annual WTP of \$241 (\$104) for a large-scale federal program that aimed to enroll $90 \%$ of children in poverty under the age of 6 . Being liberal was associated with a WTP of \$633 (\$122) annually for the same program. The corresponding figures were higher (but not significantly different) for state-run programs that target $90 \%$ of children in poverty under the age of 6 . Conservatives, in contrast, did not have positive WTP values. ${ }^{13}$ The population-weighted mean WTP values calculated by weighting the mean WTP value for each group by its representation in the sample were $\$ 255$ and $\$ 313$ per year for federal and state programs, respectively. As expected, the population-weighted mean WTP values increased to \$291 and \$366 for federal and state programs, respectively after dropping protest responses ( $7 \%$ of the sample) due to tax aversion. However, the increases were not statistically significant.

The mean annual WTP estimates for the early-childhood program in the DCE survey were based on Models 2 and 3 presented in Table 4. Respondents who indicated that a federal program would be effective or neutral were willing to pay $\$ 72$ (\$9) per year for a 50\% increase in the early-childhood program (enrolling 640,000 children). They also were willing to pay $\$ 203$ (\$12) to avoid a 50\% reduction in the early-childhood program (enrolling 210,000 children). Those who perceived the program to be ineffective did not have positive willingness to pay for increases

13 Calculated WTP values for conservatives actually were negative. This result should be interpreted as zero or no willingness to pay. The negative WTP is an artifact of distributional assumptions and/or the fact that the bid range selected was very high for conservatives. 
Table 5 Mean annual WTP per household in 2015 dollars (standard errors in parenthesis).

\begin{tabular}{|c|c|c|c|c|c|c|}
\hline & Effective & $\begin{array}{l}\begin{array}{l}\text { Not } \\
\text { effective }\end{array} \\
\end{array}$ & Moderate & Liberal & Conservative & $\begin{array}{l}\text { Weighted } \\
\text { mean }^{\dagger}\end{array}$ \\
\hline \multicolumn{7}{|c|}{ CV survey, early-childhood program (Model 3) } \\
\hline $\begin{array}{l}\text { Federal-level large- } \\
\text { scale program }\end{array}$ & $\begin{array}{r}\$ 241 * * \\
(104)\end{array}$ & $\$ 0^{\S}$ & $\begin{array}{l}\$ 162 \\
(113)\end{array}$ & $\begin{array}{r}\$ 633 * * * \\
(122)\end{array}$ & $\$ 0^{\S}$ & $\$ 255$ \\
\hline $\begin{array}{l}\text { State-level large- } \\
\text { scale program }\end{array}$ & $\begin{array}{r}\$ 344 * * \\
(105)\end{array}$ & $\$ 0^{\S}$ & $\begin{array}{r}\$ 246^{* *} \\
(115)\end{array}$ & $\begin{array}{r}\$ 716^{* * * *} \\
(125)\end{array}$ & $\$ 0^{\S}$ & $\$ 313$ \\
\hline \multicolumn{7}{|c|}{ DCE survey, early-childhood program (Model 2) } \\
\hline $\begin{array}{l}50 \% \text { decrease/enrolling } \\
210,000 \text { children }\end{array}$ & $\begin{array}{r}\$ 203 * * * \\
(12)\end{array}$ & $\begin{array}{r}\$ 39 * * \\
(15)\end{array}$ & $N A$ & $N A$ & $N A$ & $\$ 93$ \\
\hline $\begin{array}{l}50 \% \text { increase/enrolling } \\
640,000 \text { children }\end{array}$ & $\begin{array}{r}\$ 72 * * * \\
(9)\end{array}$ & $\begin{array}{r}\$ 7 \\
(14)\end{array}$ & $N A$ & $N A$ & $N A$ & $\$ 31$ \\
\hline \multicolumn{7}{|c|}{ DCE survey, early-childhood program $($ Model 3$) \ddagger$} \\
\hline $\begin{array}{l}50 \% \text { decrease/enrolling } \\
210,000 \text { children }\end{array}$ & $N A$ & $N A$ & $\begin{array}{r}\$ 156^{* * * *} \\
(14)\end{array}$ & $\begin{array}{r}\$ 236 * * * \\
(19)\end{array}$ & $\begin{array}{r}\$ 85^{* * * *} \\
(17)\end{array}$ & $\$ 158$ \\
\hline $\begin{array}{l}50 \% \text { increase/enrolling } \\
640,000 \text { children }\end{array}$ & $N A$ & $N A$ & $\begin{array}{r}\$ 52^{* * * *} \\
(12)\end{array}$ & $\begin{array}{r}\$ 99 * * * \\
(14)\end{array}$ & $\begin{array}{l}\$ 10 \\
(14)\end{array}$ & $\$ 54$ \\
\hline
\end{tabular}

\footnotetext{
$\dagger$ This was calculated by weighting the mean WTP for each group with its representation in the sample. For example, moderates constituted $40 \%$ of the sample, while liberals and conservatives constituted $30 \%$ each.

$\ddagger$ The WTP values for the CV survey were based on Model 3 presented in Table 3, and the WTP values for the DCE survey were based on Models 2 and 3 presented in Table 4 . They were converted from 2012 to 2015 dollars using the CPI inflation calculator presented at the Bureau of Labor Statistics website (http://www.bls.gov/data/inflation_calculator.htm).

$\S$ WTP values for conservatives and those who reported these programs to be ineffective were negative. This result should be interpreted as zero or no willingness to pay. The negative WTP is an artifact of distributional assumptions and/or the fact that the bid range selected was very high for these respondents.
}

in the program, but they were willing to pay $\$ 39$ (\$15) per year to avoid a $50 \%$ reduction.

Liberals on average were willing to pay $\$ 156(\$ 14)$ per year for a $50 \%$ increase in the program while moderates were willing to pay $\$ 52$ (\$12) per year. Conservatives did not have positive willingness to pay for this outcome. The populationweighted mean WTP was $\$ 54$ annually, for a 50\% increase in the early-childhood program in the DCE survey. Respondents from all three ideological groups were willing to pay to avoid decreases in the early-childhood program. Liberals were willing to pay $\$ 236(\$ 19)$ to avoid a 50\% reduction in the program, while mod- 
erates and conservatives were willing to pay $\$ 156(\$ 14)$ and $\$ 85$ (\$17) per year, respectively. The population-weighted mean WTP to avoid a 50\% reduction in the program was $\$ 158$ annually.

\section{Discussion and conclusions}

This study derived money-equivalent values for government programs for earlychildhood development as a means of reducing childhood poverty. To account for attitudes about government centralization, a CV survey was used to assess individuals' willingness to pay for high-quality, intensive early-childhood development programs at federal and state levels. A DCE survey investigated respondents' budgetary preferences for increasing and reducing the early-childhood program with associated impacts on individual tax burdens. This survey was developed to avoid possible aversion to tax increases by offering respondents options that included smaller government and lower levels of public spending. The early-childhood program was compared to other government programs with similar budget sizes to help respondents consider the opportunity cost of public dollars.

We confirmed that respondents' stated preferences for such programs were strongly influenced by political ideology and perceived effectiveness, factors generally ignored in conventional benefit-cost analysis. Although the services evaluated in the two surveys were somewhat different, we found $\mathrm{CV}$ values were considerably larger than DCE values, presumably reflecting the effect of the more realistic, policy-relevant, budget-constrained context of the DCE preference elicitation. The weak influence of traditional benefit-cost studies on policy decisions may reflect the importance of such context factors to voters and decision makers.

We found that respondents cared greatly about how childhood poverty was reduced, not just reducing poverty per se. We hypothesized that perceived effectiveness of a program, ideological perspective, opinion on the legitimate role of government, the scale of the program, and the type of institution affect individuals' preferences over a government program on early-childhood development. While the scale of the program and the type of institution did not matter in this study, perceived effectiveness of a program and ideological perspective were important determinants of stated preferences for a poverty-reduction program.

One of the most important findings of our study is that respondents across all groups, including conservatives and respondents who perceived the effectiveness of early-childhood programs to be low were not in favor of reducing the early-childhood program. These respondents, even though they opposed government involvement or did not think the programs were effective in reducing poverty, 
supported retaining government programs for children who are already enrolled. This also appears to be the case for conservatives who did not want to reduce the program although they did not want to pay for program increases. The more traditional CV method of focusing only on program improvements or increases could have indicated that conservatives and those who were skeptical about the effectiveness of early-childhood programs did not care about children in poverty. However, findings from the DCE study showed that this was not the case.

As noted, previous BCA studies early-childhood development programs calculated benefits of these programs using cost savings. This approach underestimates the total social benefits of investments in such programs. However, values are commonly higher than cost savings and values elicited from SP studies can be used as shadow values in BCA studies. Our study has several limitations. First, there is latency between the investment in early-childhood program and when benefits such as reduced crime rate or increased earnings as adults for program participants would be realized. This paper assumed that survey respondents took the effect of latency into consideration when they answered the questions. Second, the WTP values estimated in the CV and DCE surveys presumably included pure altruism which should be excluded from benefit-cost analysis to avoid double counting of the benefits received by the altruists and beneficiaries. Finally, even though KN's general population panel is representative of the US population, our sample of respondents receiving income-tax credits was much lower than expected. This apparent undersampling could be a consequence of the screening questions. The screening questions to identify the "income-tax credit" version were only asked of those who were considered to be living in poverty according to the definition of the U.S. Census Bureau, based on their annual household incomes and household sizes as archived by KN. Any respondent who received income-tax credits but had income above the defined poverty income threshold were assigned to the "tax" version.

Future research could investigate whether an early-childhood program managed by churches, charities, or private institutions would receive support from all parts of the political spectrum. Social impact bond arrangements can provide an opportunity for private investors and foundations to finance the scaling up of effective (Temple \& Reynolds, 2015). Also, respondents could be influenced by the likelihood that they would directly benefit from an effective early-childhood program. Although the sample included participants in current government programs, the current study focused on overall benefits to society rather than on participant benefits. Parents of a disadvantaged child might be willing to pay part of the costs of their child's participation in an intensive early-childhood program. Therefore, the respondents whose children or relatives were current program participants could have underestimated the potential benefits they would receive from an effective 
early-childhood program. Intangible benefits also should be considered in future studies, because child participants receive benefits such as better and more productive quality of life in the long run, and their current and future families would also benefit from these advantages.

Acknowledgment: This study is funded by the John D. and Catherine T. MacArthur Foundation. We are grateful to Michael Stegman and Vic Adamowicz who provided useful feedback throughout the development of our research. We benefitted from discussions and comments from Kerry V. Smith, Glenn Harrison, Michael Haneman and Greg Characklis, and the participants of the Benefit-Cost Analysis Conference in D.C. in October 2009 and RTI Health Preference Assessment Seminar in September 2012. We also would like to thank Juan Marcos Gonzalez for his help with the coding of the econometric modeling.

\section{Appendix A. CV question}

\section{A.1 Federal version}

If the Congress approved the new intensive early-childhood development program, the program would be paid for by increasing federal taxes. Suppose that the increased taxes your household and households like yours would have to pay for the new intensive early-childhood development programs would be \$[bid] per year. How would you want your representative to vote?

Please also remember that an increase in your taxes means you have to reduce spending on other items in your budget.

\section{A.1.1 Federal - small-scale version}

\section{Here are the options we want you to think about:}

- For Congress moving the poor children under 6 who are currently in an existing government program like Head Start into the new intensive earlychildhood development program and FOR increasing taxes for my household and other households like mine by $\$[$ bid] per year; or

- Against Congress moving poor children under 6 who are currently in an existing government program like Head Start into the new intensive earlychildhood development program; and AGAINST increasing taxes for my household and other households like mine by $\$[$ bid] per year. 


\section{A.1.2 Federal - large-scale version}

\section{Here are the options we want you to think about:}

- For Congress enrolling almost all (90\%) children living in poverty under the age of 6, including all the children now in programs like Head Start, in the new intensive early-childhood development programs, and FOR increasing taxes for my household and other households like mine by $\$$ [bid] per year; or

- Against Congress enrolling almost all (90\%) children living in poverty under the age of 6, including all the children now in programs like Head Start, in the new intensive early-childhood development programs, and AGAINST increasing taxes for my household and other households like mine by $\$[\mathrm{bid}]$ per year.

\section{A.2 State version}

If the state legislature approved the new intensive early-childhood development program, the program would be paid for by increasing state taxes. Suppose that the increased taxes your household and households like yours would have to pay for the new intensive early-childhood development programs would be $\$[$ bid] per year. How would you want your representative to vote?

Please also remember that an increase in your taxes means you have to reduce spending on other items in your budget.

\section{A.2.1 State - small-scale version}

\section{Here are the options we want you to think about:}

- For the state legislature moving the poor children under 6 who are currently in an existing government program like Head Start in [STATE] into the new intensive early-childhood development program and FOR increasing state taxes for my household and other households like mine by $\$[$ bid] per year; or

- Against the state legislature moving the poor children under 6 who are currently in an existing government program like Head Start in [STATE] into the new intensive early-childhood development program and AGAINST increasing state taxes for my household and other households like mine by $\$[$ bid] per year. 


\section{A.2.2 State - large-scale version}

\section{Here are the options we want you to think about:}

- For the state legislature enrolling almost all (90\%) children living in poverty under the age of 6 in [STATE], including the children now in programs like Head Start, in the new intensive early-childhood development programs, and FOR increasing state taxes for my household and other households like mine by $\$[$ bid] per year; or

- Against the state legislature enrolling almost all (90\%) children living in poverty under the age of 6 in [STATE], including the children now in programs like Head Start, in the new intensive early-childhood development programs, and AGAINST increasing state taxes for my household and other households like mine by $\$[$ bid] per year.

\section{References}

Alesina, Alberto \& Angeletos, George-Marios (2005). Fairness and Redistribution: U.S. Versus Europe. American Economic Review, 95(4), 960-980.

Alesina, Alberto \& La Ferrara, Eliana (2005). Preferences for Redistribution in the Land of Opportunities. Journal of Public Economics, 89(5), 897-931.

Barnett, W. Steven \& Masse, Leonard N. (2007). Comparative Benefit-Cost Analysis of the Abecedarian Program and its Policy Implications. Economics of Education Review, 26(1), 113-125.

Belfield, Clive, Brooks Bowden, A., Klapp, Alli, Levin, Henry, Shand, Robert \& Zander, Sabine (2015). The Economic Value of Social and Emotional Learning. Journal of Benefit-Cost Analysis, 6(03), 508-544.

Benabou, Roland \& Ok, Efe A. (2001). Social Mobility and the Demand for Redistribution: The Poum Hypothesis. The Quarterly Journal of Economics, 116(2), 447-487.

Bergstrom, John C., Boyle, Kevin J. \& Yabe, Mitsuyasu (2004). Trading Taxes Versus Paying Taxes to Value and Finance Public Environmental Goods. Environmental and Resource Economics, 28(4), 533-549.

Bishop, Richard C. \& Welsh, Michael P. (1992). Existence Values in Benefit-Cost Analysis and Damage Assessment. Land Economics, 405-417.

Chang, Linchiat \& Krosnick, Jon A. (2010). Comparing Oral Interviewing with Self-administered Computerized Questionnaires An Experiment. Public Opinion Quarterly 74(1), $154-167$.

Diener, Alan, O’Brien, Bernie \& Gafni, Amiram (1998). Health Care Contingent Valuation Studies: A Review and Classification of the Literature. Health Economics, 7(4), 313-326.

Duncan, Greg J., Magnuson, Katherine, Kalil, Ariel \& Ziol-Guest, Kathleen (2012). The Importance of Early Childhood Poverty. Social Indicators Research, 108(1), 87-98.

Fong, Christina (2001). Social Preferences, Self-interest, and the Demand for Redistribution. Journal of Public economics, 82(2), 225-246. 
Greene, W. H. (2007). NLOGIT Version 4.0: Reference Guide. Plainview, NY: Econometric Software Inc.

Heberlein, Thomas A., Wilson, Matthew A., Bishop, Richard C. \& Schaeffer, Nora Cate (2005). Rethinking the Scope Test as a Criterion for Validity in Contingent Valuation. Journal of Environmental Economics and Management, 50(1), 1-22.

Heckman, James J. (2008). Schools, Skills, and Synapses. Economic Inquiry, 46(3), 289-324. Heckman, James J. \& LaFontaine, Paul A. (2010). The American High School Graduation Rate: Trends and Levels. The Review of Economics and Statistics, 92(2), 244-262.

Heckman, James J., Moon, Seong Hyeok, Pinto, Rodrigo, Savelyev, Peter A. \& Yavitz, Adam (2010). The Rate of Return to the High Scope Perry Preschool Program. Journal of Public Economics, 94(1), 114-128.

Heerwegh, Dirk (2009). Mode Differences Between Face-to-Face and Web Surveys: An Experimental Investigation of Data Quality and Social Desirability Effects. International Journal of Public Opinion Research, 21(1), 111-121.

Holbrook, Allyson L. \& Krosnick, Jon A. (2010). Social Desirability Bias in Voter Turnout Reports Tests Using the Item Count Technique. Public Opinion Quarterly, 74(1), 37-67.

Holzer, Harry J., Schanzenbach, Diane Whitmore, Duncan, Greg J. \& Ludwig, Jens (2008). The Economic Costs of Childhood Poverty in the United States. Journal of Children and Poverty, 14(1), 41-61.

Jacoby, William G. (1994). Public Attitudes Toward Government Spending. American Journal of Political Science, 336-361.

Jacoby, William G. (2006). Value Choices and American Public Opinion. American Journal of Political Science, 50(3), 706-723.

Johnson, F. Reed, Kanninen, Barbara, Bingham, Matthew \& Özdemir, Semra (2007). Experimental Design for Stated-Choice Studies. In Valuing Environmental Amenities Using Stated Choice Studies (pp. 159-202). The Netherlands: Springer.

Johnston, Robert J., Swallow, Stephen K. \& Weaver, Thomas F. (1999). Estimating Willingness to Pay and Resource Tradeoffs with Different Payment Mechanisms: An Evaluation of a Funding Guarantee for Watershed Management. Journal of Environmental Economics and Management, 38(1), 97-120.

Kahneman, Daniel \& Sugden, Robert (2005). Experienced Utility as a Standard of Policy Evaluation. Environmental and Resource Economics, 32(1), 161-181.

Karoly, Lynn A. (2012). Toward Standardization of Benefit-Cost Analysis of Early Childhood Interventions. Journal of Benefit-Cost Analysis, 3(1), 1-45.

Koford, Brandon C. (2010). Public Budget Choices and Private Willingness to Pay. Public Budgeting \& Finance, 30(2), 47-68.

Kreuter, Frauke, Presser, Stanley \& Tourangeau, Roger (2008). Social Desirability Bias in CATI, IVR, and Web Surveys the Effects of Mode and Question Sensitivity. Public Opinion Quarterly, 72(5), 847-865.

Lindhjem, Henrik \& Navrud, Stale (2011). Using Internet in Stated Preference Surveys: A Review and Comparison of Survey Modes. International Review of Environmental and Resource Economics, 5, 309-351.

McFadden, Daniel \& Train, Kenneth (2000). Mixed MNL Models for Discrete Response. Journal of Applied Econometrics, 15(5), 447-470.

Mitchell, Robert Cameron \& Carson, Richard T. (2013). Using Surveys to Value Public Goods: The Contingent Valuation Method. Routledge. 
Norton, Michael I. \& Ariely, Dan (2011). Building a Better America - One Wealth Quintile at a Time. Perspectives on Psychological Science, 6(1), 9-12.

Ozdemir, Semra, Johnson, F. Reed \& Whittington, Dale (2016). Ideology, Public Goods and Welfare Valuation: An Experiment on Allocating Government Budgets. Journal of Choice Modelling, in press, corrected proof.

Rainer, Helmut \& Siedler, Thomas (2008). Subjective Income and Employment Expectations and Preferences for Redistribution. Economics Letters, 99(3), 449-453.

Revelt, David \& Train, Kenneth (2000). Customer-Specific Taste Parameters and Mixed Logit: Households' Choice of Electricity Supplier. Department of Economics, UCB.

Sas, Sas, and STAT User's Guide. (1990). SAS Institute Inc., Cary, NC 355.

Stevens, Thomas H., DeCoteau, Nichole E. \& Willis, Cleve E. (1997). Sensitivity of Contingent Valuation to Alternative Payment Schedules. Land Economics, 73(1), 140-148.

Swallow, Stephen K. \& McGonagle, Michael P. (2006). Public Funding of Environmental Amenities: Contingent Choices Using New Taxes or Existing Revenues for Coastal Land Conservation. Land Economics, 82(1), 56-67.

Temple, Judy A. \& Reynolds, Arthur J. (2015). Using Benefit-Cost Analysis to Scale Up Early Childhood Programs through Pay-for-Success Financing. Journal of Benefit-Cost Analysis, 6(03), 628-653.

Whittington, Dale, Smith, V. Kerry, Okorafor, Apia, Okore, Augustine, Liu, Jin Long \& McPhail, Alexander (1992). Giving Respondents Time to Think in Contingent Valuation Studies: A Developing Country Application. Journal of Environmental Economics and Management, 22(3), 205-225. 